\title{
PENINGKATAN KETERAMPILAN MENGEMUKAKAN PENDAPAT SISWA PADA PELAJARAN PKN MELALUI PENERAPAN MODEL PEMBELAJARAN SNOWBALL THROWING DI KELASXI IPA-1 SMA NEGERI 1 PANYABUNGAN
}

\author{
Lesna Tarida \\ Guru SMA Negeri 1 Panyabungan \\ Surel : lesna.tarida@yahoo.com
}

\begin{abstract}
Abstrak
Penelitian ini menerapkan model pembelajaran snowball throwing sebagai upaya meningkatkan aktivitas belajar dan hasil belajar yang bermuara pada peningkatan keterampilan mengemukakan pendapat siswa pada mata pelajaran PKn. Siklus I mencapai rata-rata 69,09 dengan ketuntasan klasikal 36,36\% dan Siklus II mencapai 86,97 dengan ketuntasan klasikal 90,90\%. Data aktivitas siswa menurut pengamatan pengamat pada Siklus I antara lain menulis dan membaca (47\%), mengerjakan LKS (34\% ), bertanya pada teman (4\%), menjawab pertanyaan teman (4\%), bertanya kepada guru (3\%), dan yang tidak relevan dengan KBM (9\%). Data aktivitas siswa menurut pengamatan pada Siklus II antara lain menulis dan membaca (31\%), mengerjakan LKS (44\%), bertanya pada teman $(11 \%)$, menjawab pertanyaan $(9 \%)$, bertanya kepada guru $(1 \%)$, dan yang tidak relevan dengan $\mathrm{KBM}(3 \%)$.
\end{abstract}

Kata Kunci : Model, Snowball Throwing, Hasil belajar

\section{PENDAHULUAN}

Pendidikan merupakan kebutuhan manusia sepanjang hidup dan selalu berubah seiring dengan perkembangan zaman, teknologi, dan budaya masyarakat. Kualitas pendidikan, sebagai salah satu pilar pengembangan sumber daya manusia yang bermakna, sangat penting bagi pembangunan nasional. Bahkan dapat dikatakan masa depan bangsa bergantung pada keberadaan pendidikan yang berkualitas yang berlangsung di masa kini.

Pendidikan di Indonesia diharapkan dapat mempersiapkan peserta didik menjadi warga Negara yang memiliki komitmen kuat dan konsisten untuk mempertahankan
Negara Kesatuan Republik

Indonesia. Komitmen yang kuat dan konsisten terhadap prinsip dan semangat kebangsaan dalam kehidupan bermasyarakat, berbangsa dan bernegara yang berdasarkan Pancasila dan UUD 1945, perlu ditingkatkan terus menerus untuk memberikan pemahaman yang mendalam tentang Negara Kesatuan Republik Indonesia. Konstitusi Negara Republik Indonesia perlu ditanamkan kepada seluruh komponen bangsa Indonesia, khususnya generasi muda sebagai generasi penerus.

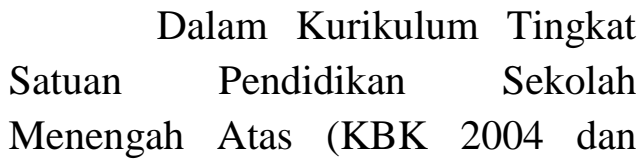


Standar Isi 2006) ditegaskan bahwa : I. Tujuan Pendidikan Menengah Atas adalah meningkatkan kecerdasan, pengetahuan, kepribadian, akhlak mulia, serta keterampilan untuk hidup mandiri dan mengikuti pendidikan lebih lanjut sesuai dengan kejuruannya, II. Standar Isi dan Standar Kompetensi Lulusan. Standar isi Pendidikan Kewarganegaraan SMA/SMK/MA : 1) Memahami hakekat Bangsa dan Negara kesatuan Republik Indonesia, 2) Menganalisis sikap positif terhadap penegakan hukum, peradilan nasional, dan tindakan anti korupsi, 3) Meganalisis pola-pola dan partisipasi aktif dalam pemajuan, penghormatan serta penegakan HAM baik di Indonesia maupun luar negeri, 4) Menganalisis peran dan hak warganegara dan sistem pemerintahan Negara Kesatuan Repbulik Indonesia, 5) Menganalisis budaya politik demokrasi, konstitusi, kedaulatan Negara, keterbukaan dan keadilan di Indonesia, 6) Mengevaluasi hubungan Internasional dan sistem hukum internasional, 7) Mengevaluasi sikap berpolitik dan bermasyarakat madani sesuai dengan pancasila dan UUD 1945, 8) Menganalisis peran Indonesia dalam politik dan hubungan Internasional, regional dan kerjasama Global lainnya, 9) Menganalisis sistem hukum internasional, timbulnya konflik internasional, dan mahkamah internasional. Dari Standar Isi dan Standar Kompetensi tersebut diatas, penulis memilih butir keenam yaitu mengevaluasi hubungan Internasional dan sistem hukum internasional, sebagai landasan judul penelitian tindakan kelas ini.

Berdasarkan hasil pengamatan dan pengalaman selama ini, siswa kurang aktif dalam kegiatan belajar-mengajar. Siswa cenderung tidak begitu tertarik dengan pelajaran PKn karena selama ini pelajaran PKn dianggap sebagai pelajaran yang hanya mementingkan hafalan semata, kurang menekankan aspek penalaran sehingga menyebabkan rendahnya keterampilan mengemukakan pendapat belajar PKn siswa di sekolah.

Banyak faktor yang menyebabkan hasil belajar PKn siswa rendah yaitu faktor internal dan eksternal dari siswa. Faktor internal antara lain: motivasi belajar, intelegensi, kebiasan dan rasa percaya diri. Sedangkan faktor eksternal adalah faktor yang terdapat di luar siswa, seperti; guru sebagai Pembina kegiatan belajar, strategi pembelajaran, sarana dan prasarana, kurikulum dan lingkungan.

Dari kenyataan tersebut dapat diduga penyebab rendahnya hasil

belajar siswa antara lain siswa kurang memahami konsep pengajaran

Pancasila sebagai ideologi terbuka, siswa kurang termotivasi menyelesaikan tugas-tugas, minat baca siswa terhadap buku teks 
PKn, guru dalam kegiatan belajar mengajar cenderung menggunakan metode ceramah sehingga materi yang diajarkan menjadi verbal/hafalan sehingga siswa bosan dan malas mengikuti pelajaran. Maka setelah observasi awal bersama guru pengampu mata pelajaran dan kolaborator mencari pemecahan masalah untuk meningkatkan keaktifan dan hasil belajar siswa yang berujung pada meningkatkan keterampilan mengemukakan pendapat siswa pada belajar PKn diperoleh hasil diskusi bahwa dilakukannya perubahan metode pembelajaran yaitu dengan penyajian pembelajaran dibuat lebih menarik. Dengan menggunakan pembelajaran kooperatif tipe snowball throwing diharapkan akan menjadi solusi dan dapat menarik perhatian siswa sehingga siswa akan lebih aktif dalam pembelajaran dan akan menciptakan suasana lebih segar serta mengurangi kejenuhan dalam kelas. Dengan lebih aktifnya siswa diharapan akan meningkatkan keterampilan mengemukakan pendapat siswa dalam mata pelajaran PKn.

Berdasarkan latar belakang di atas maka peneliti ingin melakukan penelitian dengan menerapkan model pembelajaran kooperatif tipe Snowball Throwing selama KBM yang akan peneliti lakukan di kelas yang cenderung memiliki masalah yakni di kelas XI IPA-1.
Berdasarkan judul penelitian, maka yang menjadi identifikasi masalah dalam penelitian ini yakni:

a. Masih banyak guru yang menempatkan siswa sebagai objek sehingga menyebabkan siswa pasif dalam kegiatan pembelajaran

b. Rendahnya aktivitas belajar siswa.

c. Kurangnya kemampuan siswa dalam mengemukakan pendapat.

d. Guru tidak menggunakan media pada saat mengajar

e. Kurangnya kesadaran berkelompok untuk mengerjakan tugas-tugas PKn.

f. Kurangnya minat siswa untuk bertanya mengenai materi yang diajarkan maupun memberi jawaban jika guru memberi pertanyaan.

Untuk menyelesaikan masalahmasalah yang dihadapi siswa, maka peneliti membatasi permasalahan sesuai dengan kemampuan peneliti antara lain;

a. Model pembelajaran yang digunakan adalah model pembelajaran kooperatif tipe snowball throwing.

b. Kualitas pembelajaran dibatasi pada peningkatan aktivitas siswa dan hasil belajar setelah menerima pengalaman belajar PKn pada materi Pokok Hubungan Internasional. 
c. Subjek penelitian adalah siswa kelas XI IPA-1, Panyabungan tahun pelajaran 2014/2015.

d. Materi pembelajaran dalam penelitian ini dibatasi pada pokok bahasan Hubungan Internasional.

e. Kurikulum yang digunakan adalah KTSP

Untuk memperjelas masalah yang akan dibahas, maka yang menjadi rumusan-rumusan dalam penelitian ini adalah:

a. Apakah model pembelajaran kooperatif tipe Snowball Throwing dapat meningkatkan keterampilan mengemukakan pendapat siswa dalam belajar PKn?

b. Bagaimana penerapan model pembelajaran kooperatif tipe Snowball Throwing di kelas dalam mata pelajaran $\mathrm{PKn}$ ?

c. Apakah model pembelajaran kooperatif tipe Snowball Throwing dapat meningkatkan hasil belajar siswa?

Setelah menetapkan rumusan masalah di atas, maka dapat ditentukan tujuan penelitian ini, antara lain;

a. Untuk mengetahui apakah penerapan model pembelajaran kooperatif tipe Snowball Throwing dapat meningkatkan keterampilan mengemukakan pendapat siswa dalam belajar PKn? b. Untuk mengetahui bagaimana penerapan model pembelajaran kooperatif tipe Snowball Throwing di kelas dalam mata pelajaran PKn?

c. Untuk mengetahui apakah model pembelajaran kooperatif tipe Snowball Throwing dapat meneingkatkan hasil belajar siswa?

Dari hasil penelitian di harapkan dapat berguna bagi pihak-pihak sebagai berikut:

a. Guru:

Dapat memanfaatkan hasil penelitian sebagai masukan untuk melihat kekurangan dan kelebihan dalam mengajar sehingga dapat di upayakan tindakan-tindakan perbaikan pembelajaran lebih lanjut di antaranya dengan metode pembelajaran kooperatif snowball throwing.

b. Kepala sekolah:

Dapat menggunakan hasil penelitian sebagai masukan atau referensi untuk meningkatkan kualitas pembelajaran di sekolahnya dengan mendorong guru yang lain dengan metode pembelajaran kooperatif snowball throwing.

c. Peneliti:

Untuk memperkaya pengetahuan untuk meneliti berbagai penelitian dan mengetahui bahwasanya di lapangan banyak permasalahan dalam pembelajaran sehingga saat terjun ke lapangan sudah bisa 
mengantisipasi atau meminimalisir masalah yang ada.

\section{Menurut Arikunto}

(2003:122) yang termasuk kategori kemampuan psikomotor adalah kemampuan yang menyangF̈̈nggi kegiatan otot sehingga menyebabkan geraknya tubuh atau bagianbagiannya. Sementara Benyamin S.

Bloom (dalam Arifin 2009:22) berpandapat bahwa ranah Psikomotorik berkenaan dengan kemampuan peserta didik yang berkaitan dengan gerakan tubuh atau bagian-bagiannya, mulai dari gerakan yang sederhana sampai dengan gerakan yang kompleks. Perubahan pola gerakan sekurangkurangnya 30 menit. Kata kerja operasional yang digunakan harus sesuai dengan kelompok keterampilan masing-masing, yaitu : 1) Muscular or motor skill, meliputi : mempertontonkan

gerak, menunjukkan hasil, melompat, menggerakkan, menampilkan, 2) Manipulations of materials or objects, : mereparasi, menyusun, membersihkan, menggeser, memindahkan, membentuk, 3) Neuromuscular coordination, meliputi : mengamati, menerapkan, menghubungkan, menggandeng, memadukan, memasang, memotong, menarik, menggunakan.

selalu menuntut pengamatan terhadap lingkungan ini dimaksudkan agar siswa mampu menentukan posisi fisik baik dirinya maupun benda kerjanya. Kondisi seperti ini sebenarnya gambaran keterkaitan yang erat antara kompetensi kognitif terhadap kompetensi psikomotorik.

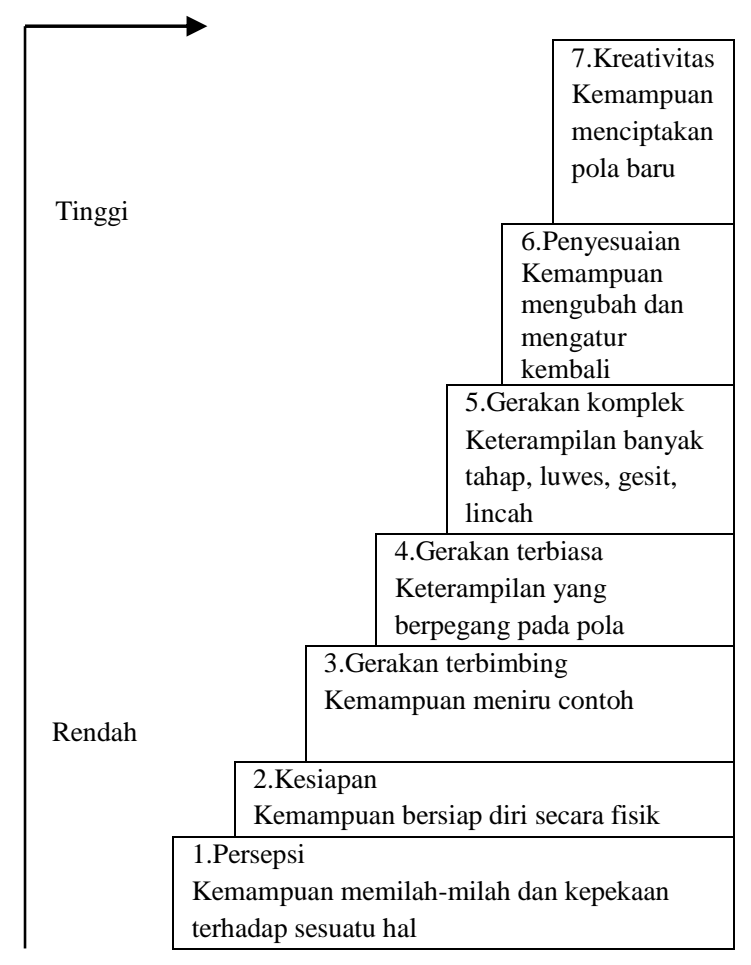

Pra belajar

Gambar.2.1 Hirarki jenis prilaku psikomotorik (Aunurrahman, 2009 : 53)

Dari beberapa pendapat di atas, maka dapat disimpulkan bahwa:

- Model pembelajaran adalah suatu rencana/rancangan pembelajaran.

- Model pembelajaran adalah kerangka acuan (pedoman) dalam kegiatan pembelajaran sehingga menghasilkan situasi lingkungan yang menyebabkan para siswa berinteraksi dengan baik dan dapat merubah tingkah laku siswa itu. 


\section{METODOLOGI PENELITIAN}

Penelitian ini dilakukan di Sekolah SMA Negeri 1 Panyabungan yang beralamat di Jalan Sutan Soripada Mulia Kecamatan Panyabungan dan pelaksanaannya selama 4 bulan mulai dari bulan Januari sampai dengan April 2015. Pengambilan data dilakukan pada bulan Pebruari 2015, berlangsung selama dua siklus dengan dua KBM setiap siklusnya.

Populasi dalam penelitian ini adalah seluruh siswa kelas XI IPA-1 SMA Negeri 1 Panyabungan. Dengan mempertimbangkan perolehan nilai terendah untuk kelas XI IPA-1, maka subjek yang digunakan dalam penelitian ini adalah seluruh siswa kelas XI IPA-1 SMA Negeri 1 Panyabungan Tahun Pelajaran 2014/2015, dengan jumlah siswa sebanyak 33 orang.

\section{Instrumen Penelitian}

Instrumen yang digunakan dalam penelitian ini adalah lembar observasi dan tes hasil belajar.

\section{Lembar Observasi}

Observasi dimaksudkan untuk mengamati aktivitas belajar siswa selama pelaksanaan pembelajaran. Observasi dilakukan oleh observer yang berjumlah dua orang dengan menggunakan lembar observasi.

Observasi dalam penelitiaan ini adalah observasi terhadap subjek penelitian yang dilakukan untuk mengetahui afektif dan aktivitas siswa selama pembelajaran. Adapun manfaat observasi dalam penelitian ini adalah untuk memperoleh gambaran tentang keseluruhan objek yaitu memperoleh informasi balikan guru di dalam kegiatan belajar mengajar. Observasi yang dilakukan bersifat langsung dan dilakukan oleh 2 orang pengamat yang dilengkapi dengan lembar pedoman observasi afektif dan aktivitas belajar siswa.

Lembar aktivitas ini digunakan pada saat siswa bekerja dalam kelompok. Yang menggunakan lembar aktivitas belajar siswa ini adalah dua orang pengamat, yang mengamati masingmasing satu kelompok setiap satu KBM yang sudah ditentukan oleh peneliti/guru. Pengamat aktivitas siswa selama KBM diambil sesama peneliti antara lain; Baijah, S.Pd dan Habibah, S.Pd. Pengamat tidak boleh duduk bersamaan untuk menghindari data bias. Pengamat mentabulasi data/menceklis pada lembar aktivitas ini selama dua menit sekali. Akhir kerja kelompok maka pengamat menandatangani lembar pengamat kemudian menyerahkan kepada peneliti. Sebagai contoh, bila kerja kelompok ditentukan oleh peneliti selama 20 menit maka pengisian data pada lembar aktivitas jumlah per siswa ada 10 ceklis. 10 ceklis ini posisinya pada 5 aktivitas ini sesuai dengan pengamatan. Setelah data terkumpul, maka data tersebut dianalisis sehingga setiap aktivitas dapat ditentukan persentasinya. 
Tes

Tes digunakan untuk mengukur hasil belajar siswa yang diberi perlakuan berupa model pembelajaran snowball throwing maupun yang tidak diberi perlakuan yaitu model pembelajaran konvensional. Instrumen yang digunakan dalam penelitian ini adalah tes hasil belajar siswa yang terdiri dari 20 soal dalam bentuk pilihan berganda dan masing-masing soal memiliki 5 option Salah satu option merupakan kunci jawaban, sedangkan 4 option lainnya sebagai pengecoh. Adapun kisi - kisi tesnya sebagai berikut :

Tabel 3.1. Kisi-kisi test hasil belajar siswa

\begin{tabular}{|c|c|c|c|c|c|c|c|}
\hline \multirow{2}{*}{$\begin{array}{l}\text { No. } \\
\text { Butir } \\
\text { Soal }\end{array}$} & \multicolumn{6}{|c|}{ Klasifikasi } & \multirow[t]{2}{*}{ Jumlah } \\
\hline & $\begin{array}{l}\mathrm{C} \\
1\end{array}$ & $\begin{array}{l}\mathrm{C} \\
2\end{array}$ & $\begin{array}{l}\mathbf{C} \\
3\end{array}$ & $\begin{array}{l}\text { C } \\
4\end{array}$ & $\begin{array}{l}\mathrm{C} \\
5\end{array}$ & $\begin{array}{l}\mathrm{C} \\
6\end{array}$ & \\
\hline 1 & & $\sqrt{ }$ & & & & & \\
\hline 2 & & & & $\sqrt{ }$ & & & \\
\hline 3 & & & & $\sqrt{ }$ & & & \\
\hline 4 & $\sqrt{ }$ & & & & & & \\
\hline 5 & $\sqrt{ }$ & & & & & & \\
\hline 6 & $\sqrt{ }$ & & & & & & \\
\hline 7 & & $\sqrt{ }$ & & & & & \\
\hline 8 & $\sqrt{ }$ & & & & & & \\
\hline 9 & $\sqrt{1}$ & & & & & & \\
\hline 10 & $\sqrt{1}$ & & & & & & \\
\hline 11 & & $\sqrt{ }$ & & & & & \\
\hline 12 & & $\sqrt{ }$ & & & & & \\
\hline 13 & & $\sqrt{ }$ & & & & & \\
\hline 14 & & $\sqrt{ }$ & & & & & \\
\hline 15 & & $\sqrt{ }$ & & & & & \\
\hline 16 & & $\sqrt{ }$ & & & & & \\
\hline 17 & & & & $\sqrt{ }$ & & & \\
\hline 18 & & & & $\sqrt{ }$ & & & \\
\hline 19 & & $\sqrt{1}$ & & & & & \\
\hline 20 & & $\sqrt{ }$ & & & & & \\
\hline Jumlah & 6 & $\begin{array}{l}1 \\
0\end{array}$ & & 4 & & & \\
\hline
\end{tabular}

Keterangan :

C1 : Pengetahuan

C2 : Pemahaman

C3 : Aplikasi

C4 : Analisis

C5 : Sintesis

C6 : Evaluasi

Ketuntasan belajar setiap indikator yang telah ditetapkan dalam suatu kompetensi dasar berkisar antara 0-100\%. Kriteria ideal ketuntasan untuk masingmasing indikator $78 \%$. Sedangkan Ketuntasan belajar berdasarkan Kriteria Ketuntasan Minimal (KKM) di SMA Negeri 1 Panyabungan adalah 78 secara individual dan $85 \%$ secara klasikal.

Penelitian ini merupakan Penelitian Tindakan Kelas (PTK), dimana penelitian ini terdiri dari dua siklus yaitu siklus I dan siklus II. Setiap siklus terdiri dari empat tahapan rangkaian yang dilakukan dalam siklus berulang. Empat kegiatan utama yang ada pada setiap siklus yaitu tahap perencanaan, tahap pelaksanaan/tindakan, tahap pengamatan (Observasi), dan tahap refleksi( Arikuntodkk, 2007: 74 ).

Penelitian tindakan kelas ini dilakukan dalam dua siklus. Adapun tahapan pelaksanaan penelitian tindakan kelas digambarkan seperti gambar di bawah ini : 


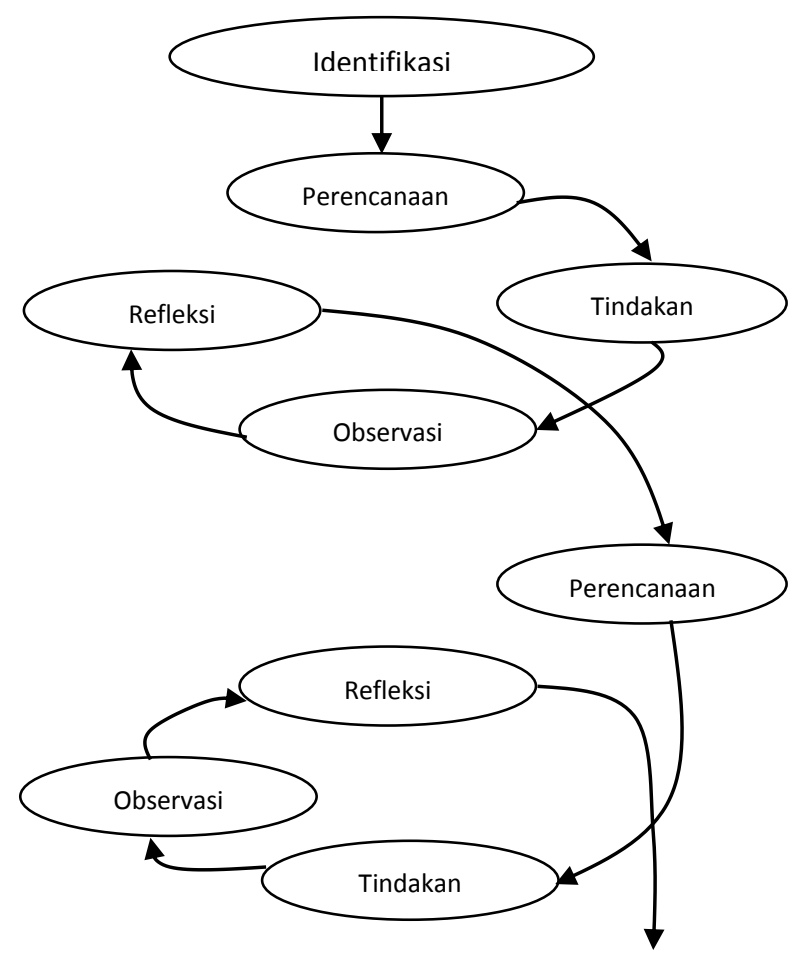

Gambar 3.1 : Spiral Tindakan Kelas

(Hopkins dalam Aqib, 2006 : 31)

Berikut rincian kegiatan pada setiap tahapan adalah sebagai berikut:

\section{Siklus I}

a. Tahap Perencanaan tindakan

Rencana kegiatan siklus I meliputi:

a) Membuat lembar observasi aktivitas belajar siswa, LKS dan soal evaluasi

b) Membuat skenario pembelajaran dengan menggunakan berbagai pola latihan yang disusun dari yang paling simple ke yang lebih kompleks c) Membuat alat bantu mengajar yakni dengan memperdayakan leptop dan infokus yang bertujuan untuk meningkatkan kemampuan siswa.

b. Tahap Pelaksanaan Tindakan

Pada tahap ini, rancangan strategi dan skenario pembelajaran yang telah disusun pada perencanaan tindakan akan diterapkan dalam upaya meningkatkan

keterampilan

mengemukakan pendapat siswa serta aktivitas dan hasil belajar pada siswa kelas XI IPA-1 pada pokok bahasan Hubungan Internasional dengan menerapkan model pembelajaran snowball throwing. Tindakan dilakukan oleh peneliti sendiri yang berlangsung di dalam kelas dengan berpedoman pada kurikulum, silabus mata pelajaran dan rencana pembelajaran. Selain itu peneliti juga berperan untuk memberikan stimulus dan motivasi kepada siswa dengan tujuan agar siswa lebih aktif dan kreatif dalam proses belajar mengajar 
serta terampil dalam mengemukakan pendapat.

c. Tahap Observasi (Pengamatan)

a) Peneliti mengamati dan mencatat setiap kejadian yang muncul

b) Kolaborator / observer mengamati serta mencatat kedalam lembar observasi aktivitas semua hal yang berkaitan dengan kegiatan pembelajaran.

\section{d. Tahap Refleksi}

Dari hasil pengamatan dan catatan-catatan yang ada selama kegiatan siklus I berlangsung diadakan evaluasi dan perbaikan-perbaikan untuk masuk ke siklus berikutnya.

\section{Siklus II}

Pelaksanaan siklus II ini didasarkan pada hasil refleksi yang sudah dilakukan pada siklus I, mengulang tahapan-tahapan yang sudah tertera pada siklus I, siklus II juga merupakan penyempurnaan dari kekurangankekurangan yang terdapat pada siklus I dengan tujuan untuk mendapatkan hasil yang jauh lebih sempurna. Adapaun ketuntasan belajar berdasarkan kurikulum tingkat satuan pendidikan (KTSP) adalah sebagai berikut :

a. Perorangan :apabila mampu menyerap $78 \%$ dari materi yang disampaikan, yang akan terlihat pada hasil evaluasi dimana siswa dapat mencapai 78 pada saat evaluasi.

b. Klasikal : apabila $85 \%$ atau lebih dari siswa dikelas mencapai ketuntasan perorangan, yang akan terlihat pada hasil evaluasi minimal $85 \%$ mencapai 78 keatas, sehingga indicator keberhasilan dalam penelitian ini adalah tercapai ketuntasan secara klasikal.

\section{Teknik Analisis Data}

Analisis data pada penelitian ini digunakan model deskriptif dengan membandingkan hasil belajar siswa sebelum tindakan dengan hasil belajar siswa setelah tindakan.

Langkah-langkah pengolahan data sebagai berikut:

a. Merekapitulasi nilai pretes sebelum tindakan dan nilai tes akhir siklus I dan siklus II.

b. Menghitung nilai rata-rata atau persentase hasil belajar siswa sebelum dilakukan tindakan dengan hasil belajar setelah dilakukan tindakan pada siklus I dan siklus II untuk mengetahui adanya peningkatan hasil belajar. 
Penilaian

a. Data nilai hasil belajar (kognitif) diperoleh dengan menggunakan rumus:
Sebagai tolak ukur keberhasilan penelitian tindakan kelas ini dapat dilihat dari: hasil tes, jika hasil belajar siswa mencapai KKM secara individual dan 85\%

Nilai Siswa $=\frac{\text { Jumlah jawaban benar }}{\text { Jumlah seluruh soal }} \times 100$ klasikal.

(Slameto,2001:189)

b. Nilai rata-rata siswa dicari dengan rumus sebagai berikut:

$$
\bar{X}=\frac{\sum X}{N}
$$

Keterangan :

$\bar{X}=$ Nilai rata-rata

$\Sigma=$ Jumlah nilai $X$

$\mathrm{N}=$ Jumlah peserta tes

(Subino, 1987:80)

c. Untuk penilaian aktivitas digunakan rumus sebagai berikut:

\section{HASIL PENELITIAN DAN PEMBAHASAN}

SMA Negeri 1 Panyabungan beralamat di Jalan Sutan Soripada Panyabungan, Kabupaten Mandailing Natal. Berdasarkan letaknya yang berada di belakang Rumah Sakit Umum Mandailing Natal. Lokasi sekolah cukup mudah dijangkau oleh kendaraan umum dan dapat dikatakan strategis karena suasananya cukup tenang, sehingga akan mendukung kelancaran proses belajar mengajar.

$$
\begin{aligned}
& \% \text { Proporsi Aktivitas } \\
& =\frac{\text { jumlahskoryangdiperoleh }}{\text { jumlahskor ideal }} \times 100 \%
\end{aligned}
$$

(Majid, 2009:268)

d. Ketentuan persentase ketuntasan belajar kelas

Ketuntasan belajar kelas $=\frac{\sum S_{b}}{K} \times 100 \%$

$\Sigma \mathrm{Sb}=$ Jumlah siswa yang mendapat nilai $\geq 78$ (kognitif)

$\Sigma \mathrm{K}=$ Jumlah siswa dalam sampel
Rendahnya aktivitas belajar siswa terhadap pelajaran $\mathrm{PKn}$ ini berdampak terhadap hasil belajar siswa. Hal ini ditunjukkan dengan hasil tes awal yang diberikan kepada siswa untuk mengetahui sejauh mana siswa memahami materi PKn. Kondisi awal hasil tes pada siswa kelas XI IPA-1 SMA Negeri 1 Panyabungan sebelum diadakan penelitian disajikan pada Tabel 4.1. 
Table 4.1 Distribusi Hasil Pretes

\begin{tabular}{|c|c|c|c|}
\hline Nilai & Frekunsi & $\begin{array}{c}\text { Rata- } \\
\text { rata }\end{array}$ & S.D \\
\hline 35 & 2 & \multirow{8}{*}{53,64} & \multirow{8}{*}{8,32} \\
\hline 40 & 1 & & \\
\hline 45 & 5 & & \\
\hline 50 & 5 & & \\
\hline 55 & 7 & & \\
\hline 60 & 9 & & \\
\hline 65 & 4 & & \\
\hline Jumlah & 33 & & \\
\hline
\end{tabular}

Merujuk pada Tabel 4.1, nilai terendah untuk pretest adalah 35 yang diperoleh 2 orang siswa, dan tertinggi adalah 65 yang diperoleh 4 orang siswa. Dengan KKM yang ditetapkan sebesar 78 dengan tidak seorang pun mendapat nilai diatas ketuntasan atau ketuntasan secara klasikal adalah $0 \%$. Nilai rata-rata kelas adalah 53,64 dengan standar deviasi 8,32 dalam kategori tidak tuntas. Ini berarti siswa tidak mempersiapkan diri belajar dirumah untuk tiap materi baru sebelum datang ke sekolah. Data hasil pretes ini dapat disajikan kembali dalam grafik histogram sebagai berikut:

\section{Grafik Pretes}

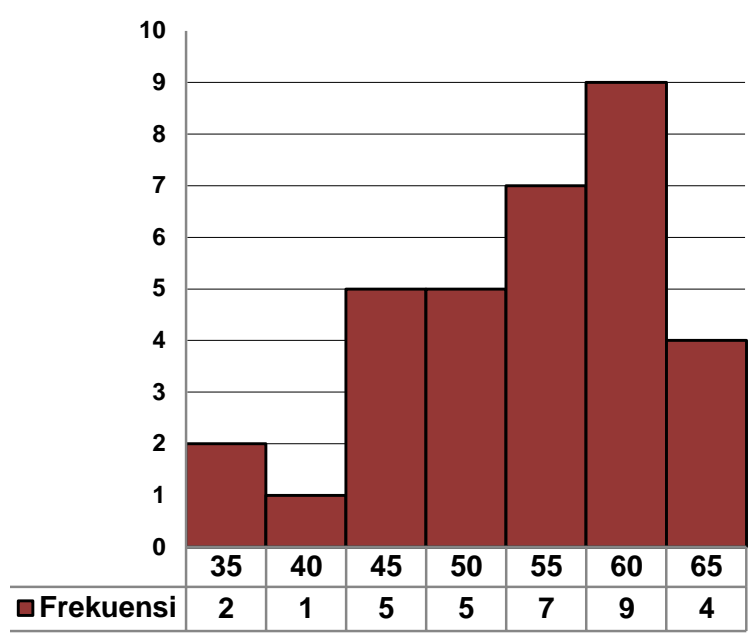

\section{Gambar .4.1 Grafik data hasil pretes}

Kenyataan

diatas, memberikan motivasi kepada peneliti dan guru PKn untuk melakukan tindakan. Tindakan yang diambil untuk meningkatkan aktivitas yang bermuara pada peningkatan hasil serta keterampilan mengemukakan pendapat siswa terhadap mata pelajaran PKn dengan menerapkan model pembelajaran kooperatif tipe Snowball Throwing.

\section{Pelaksanaan Tindakan Siklus I}

Materi yang diajarkan pada siklus I ini adalah Hubungan Internasional waktu 2 jam pelajaran yakni 2x 45 menit, dan didistribusikan dalam 1 (satu) kali pertemuan di kelas. Guru sebagai peneliti menyampaikan materi kepada siswa yang berjumlah 33 orang dengan dibantu oleh guru sesama peneliti sebagai pengamat aktivitas belajar siswa. Rekaman 
proses pembelajaran KBM 1 pada Siklus dapat dilihat sebagai berikut: Rekaman Pembelajaran KBM 1

Pada hari Senin, 16 Pebruari 2015 pada jam ke 4 dan 5 di kelas XI IPA-1 pelajaran Pendidikan Kewarganegaraan. Guru memasuki ruangan kelas XI IPA-1 dan memberikan salam "selamat pagi anakanak" dan siswa serentak menjawab salam guru dengan ucapan "selamat pagi bu.....!". "Bagaimana kabar kalian semua? Ada yang tidak hadir?". Ketua kelas menjawab, "tidak ada buk". "Baiklah kalau begitu, sebelum kita membahas materi pelajaran kita tentang Hubungan Internasional, Ibu terlebih dahulu akan memberika evaluasi (pretest).

Guru membagikan soal pretest kepada siswa. Ujian dilaksanakan \pm 20 menit sesuai dengan waktu ujian yang telah ditentukan. Guru meminta siswa untuk mengumpulkan kertas ujian. Setelah kertas ujian terkumpul semua, guru memotivasi siswa dengan menunjukkan gambar dan mengajukan beberapa pertanyaan. "Apakah pengertian hubungan internasional?" Annisa mengacungkan tangannya dan berkata, "Hubungan Internasional adalah Hubungan yang diadakan oleh suatu bangsa atau negara yang satu dengan negara yang lainnya!" Guru menjawab dengan, "Bagus sekali!"

Guru menginformasikan tujuan pembelajaran dan menjelaskan materi pelajaran tentang pengertian pengertian hubungan internasional, pentingnya hubungan internasional, dan sarana-sarana hubungan internasional bagi suatu negara.

Kemudian guru menyuruh siswa untuk membentuk kelompok dan menyuruh siswa untuk bekerja kelompok dengan kelompoknya masing-masing. Kemudian guru memanggil ketua kelompok untuk memberikan penjelasan tentang materi yang akan didiskusikan.

Pada saat diskusi, guru membimbing kelompok belajar sambil membagikan kertas kerja kepada setiap siswa dan menuliskan pertanyaan untuk diberikan kepada temannya yang lain. Sesuai dengan waktu yang telah ditentukan guru memanggil siswa untuk membaca dan menjawab pertanyaan yang diajukan oleh temannya dalam kertas bola yang dibuat temannya.

Ahmad, Azizah langsung angkat tangan untuk menambah jawaban yang diberikan oleh Annisa. Guru membuat kesimpulan pelajaran bersama-sama dengan siswa. Pada akhir pelajaran guru memberikan tugas dan menyampaikan materi untuk minggu depan. Bel istirahat pun berbunyi, guru mengucapkan, "Selamat siang dan sampai bertemu minngu depan".

Setelah KBM I siklus I dilakukan pada hari Senin, tanggal 16 Pebruari 2015, maka KBM 2, siklus I dilakukan pada hari Senin 16 Pebruari 2015. Berikut rekaman pembelajaran KBM 2, siklus I:

\section{Rekaman Pembelajaran KBM 2}

Pada hari senin, 23 Pebruari 2015 pada jam ke-4 dan ke-5 adalah mata pelajaran PKn dengan materi Tahap-tahap Perjanjian Internasional. Guru masuk kedalam ruangan kelas dan mengucapkan, "Selamat pagi". Anak-anak dengan serentak membalas ucapannya dengan berkata, "Selamat pagi buk..!" Guru bertanya kepada ketua kelas," Siapa lagi yang belum masuk?" Febriyadi menjawab, "Riado buk!” Guru

mempersiapkan perlengkapan pelajaran dan menunjukkan peta konsep tentang Tahap-tahap Perjanjian Internasional. Setelah guru menjelaskan materi 


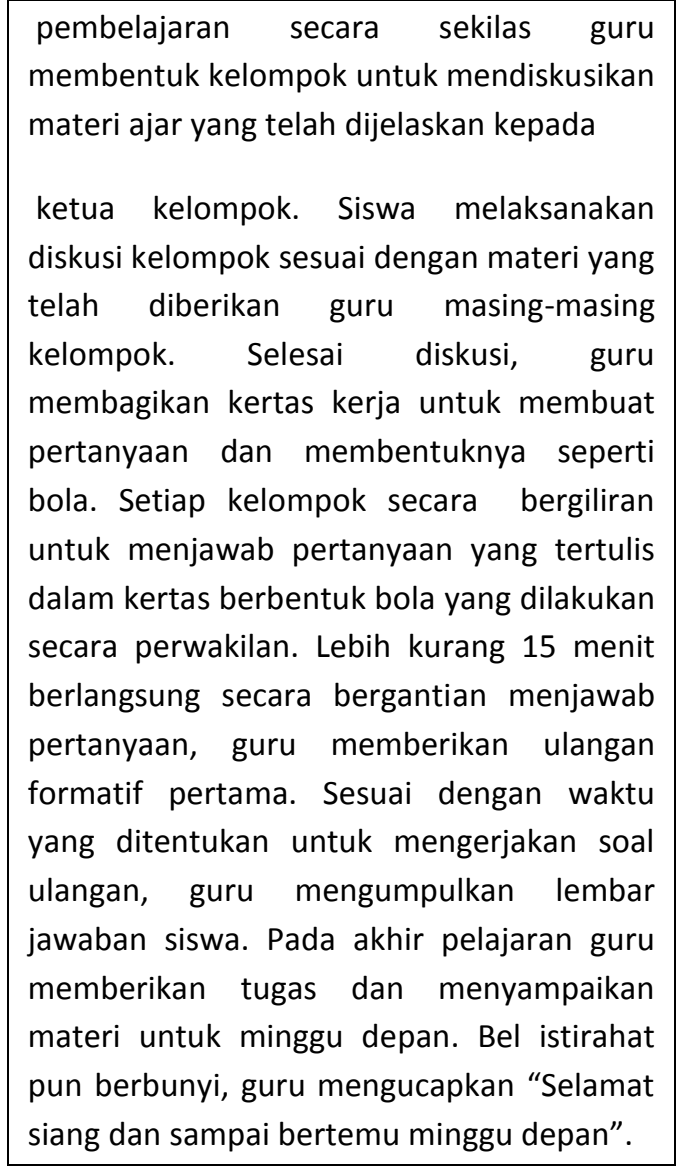

Setelah berakhirnya siklus I dengan 2 KBM diadakan tes hasil belajar berupa formatif I dengan soal adalah bagian tes awal yang indikatornya telah dipelajari. Hasil formatif I disajikan dalam Tabel 4.2 berikut:
Table 4.2 Distribusi Hasil Formatif I

\begin{tabular}{|c|c|c|c|}
\hline Nilai & Frekuensi & $\begin{array}{c}\text { Rata- } \\
\text { rata }\end{array}$ & S.D \\
\hline 40 & 3 & \multirow{3}{*}{69,09} & \multirow{2}{*}{13,78} \\
\cline { 1 - 2 } 50 & 2 & & \\
\cline { 1 - 2 } 60 & 5 & & \\
\hline 70 & 11 & & \\
\hline 90 & 9 & & \\
\hline Jumlah & 33 & & \\
\hline
\end{tabular}

Merujuk pada Tabel 4.2 tersebut, nilai terendah formatif I adalah 40 dan tertinggi adalah 90 dengan kriteria ketuntasan minimal 78 maka, hanya 12 orang mendapat nilai diatas kriteria ketuntasan atau ketuntasan klasikal adalah sebesar $36,36 \%$. Dengan mengacu pada ketuntasan klasikal minimum sebesar $85 \%$ maka nilai ini masih berada di bawah kriteria keberhasilan sehingga dapat dikatakan KBM siklus I gagal memberi ketuntasan belajar dalam kelas. Nilai rata-rata kelas adalah 69,09 dengan standar deviasi 13,78 dan tidak tuntas.

\section{Refleksi I dan Tindakan}

Setelah siklus I selesai, maka peneliti melakukan refleksi yakni melihat kekurangan-kekurangan yang terjadi selama 2 KBM yang menyebabkan nilai formatif I siswa tidak mencapai ketuntasan klasikal 
$85 \%$. Oleh karena itu peneliti berdiskusi dengan guru sejawat yang mengajarkan mata pelajaran PKn untuk mengevaluasi materi yang peneliti bawakan.

Merujuk pada rekaman pembelajaran diperoleh beberapa hal yang dapat dicatat sebagai masukan untuk perbaikan pada tindakan selanjutnya, yaitu :

a. Pembelajaran belum berpusat pada siswa

b. Bimbingan yang diberikan guru kurang menyeluruh.

c. Kelompok yang dibentuk guru tidak heterogen, karena berdasarkan letak tempat duduk siswa.

d. Guru tidak dapat memanajemen waktu dengan baik, sehingga semua kegiatan dilakukan secara tergesa-gesa. Bahkan pada KBM 2 guru tidak membimbing siswa untuk menarik kesimpulan dengan baik.

Untuk menyusun rencana pada tindakan kelas siklus II maka perlu diadakan tindakan perbaikan terencana dari tindakan kelas siklus I. Berdasarkan hasil dari refleksi siklus I, maka beberapa tindakan perbaikan yang disepakati antara peneliti dengan rekan kolaborasi, (teman sejawat guru, observer) adalah sebagai berikut :

a. Proses pembelajaran harus berpusat pada siswa. b. Perlu adanya umpan balik bagi siswa agar tahu sejauh mana pemahaman mereka terhadap materi ajar yang disampaikan.

c. Meningkatkan bimbingan siswa secara menyeluruh.

d. Mengganti kelompok diskusi siswa menjadi kelompok diskusi yang heterogen, sehingga siswa yang pintar dapat membantu teman kelompoknya yang kemampuan kognitifnya rendah.

e. Guru harus pintar memanajemen waktu sehingga semua kegiatan pembelajaran dapat terlaksana dengan baik.

\section{Tindakan kelas Siklus II}

Siklus II juga akan dilakukan dengan 2 KBM, KBM I siklus II dilakukan pada 2 Maret 2015 pada les 4 dan 5. Berikut rekaman pembelajaran KBM 3 dan 4 yang dilakukan pada siklus II.

\section{Rekaman Pembelajaran KBM 3}

Pada hari Senin, 2 Maret 2015
pada jam ke-4 dan ke-5 dengan meteri
pembelajaran Organisasi Internasional.
Siswa duduk dengan tenang pada saat guru
memasuki ruangan kelas XI IPA-1, dan
menyambut guru dengan ucapan, "Selamat
pagi bu". Guru menyuruh siswa untuk
mempersiapkan infokus dan laptop,
sementara siswa memasang infokus, guru
mengabsen siswa. Setelah selesai infokus
dan laptop dipasang siswa guru memotivasi




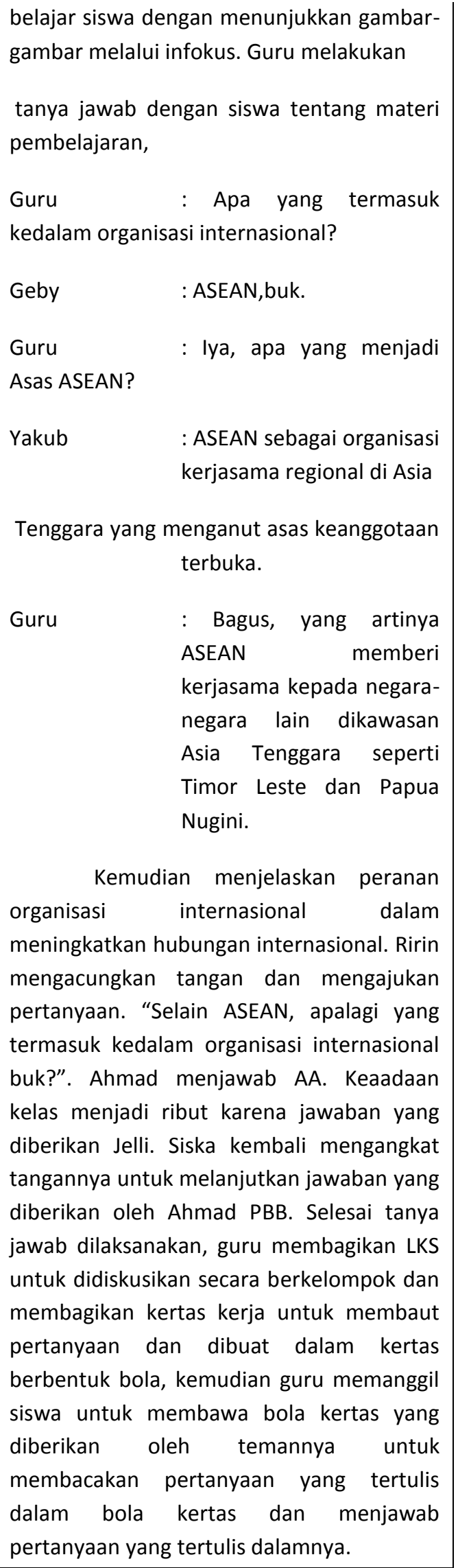

Kegiatan tersebut diakhiri dengan kesimpulan pelajaran oleh guru dan siswa.

Rekaman Pembelajaran KBM 4 siklus II.

KBM 4 dilaksanakan pada hari Senin 9 Maret 2015 dengan materi Manfaat Kerjasama dan Perjanjian Internasional. Pada saat guru masuk kedalam ruangan kelas XI IPA-1, siswa duduk sesuai dengan kelompok yang telah ditentukan oleh guru. Ahmad berkata, "Maaf ya bu ini kami lakukan agar selesai diskusi, kami semua dapat giliran untuk menjawab pertanyaan

yang ditulis dalam bola kertas. Guru menjelaskan materi pelajaran secara singkat

tentang Manfaat Kerjasama dan Perjanjian Internasional. Barata bertanya, "Mengapa kerjasama dan perjanjian internasional dikatakan sebagai kebutuhan pokok bagi setiap negara bu?". Sebelum guru menjelaskannya, Annisa langsung menjawab, "Karena setiap negara merupakan bagian dari masyarakat dunia, sehingga perlu dikembangkan sikap hormat menghormati dan bekerjasama dengan negara lain". Ya, Bagus!" Kata guru.

Guru menjelaskan secara ringkas manfaat kerjasama dan perjanjian internasional. Kemudian guru memberikan tugas kelompok dan mengevaluasi siswa dengan ulangan formatif kedua dan menilai hasil ujian siswa.

Setelah berkahirnya siklus II, guru memberikan tes yang merupakan formatif II. Hasil formatif II disajikan dalam Tabel 4.3 berikut: 
Table 4.4 Distribusi hasil Formatif II

\begin{tabular}{|c|c|c|c|}
\hline Nilai & Frekuensi & $\begin{array}{c}\text { Rata- } \\
\text { rata }\end{array}$ & S.D \\
\hline 50 & 1 & \multirow{7}{*}{86,97} & \multirow{7}{*}{12,12} \\
\hline 60 & 1 & & \\
\hline 70 & 1 & & \\
\hline 80 & 11 & & \\
\hline 90 & 9 & & \\
\hline 100 & 10 & & \\
\hline Jumlah & 33 & & \\
\hline
\end{tabular}

Merujuk pada Tabel 4.4, nilai terendah untuk formatif II adalah 50 dan tertinggi adalah 100 dengan kriteria ketuntasan minimal 78 maka 30 siswa mendapat nilai diatas kriteria ketuntasan atau ketuntasan klasikal adalah sebesar $90.90 \%$. Mengacu pada kriteria ketuntasan klasikal minimum sebesar $85 \%$ maka nilai ini berada di atas kriteria keberhasilan sehingga dapat dikatakan KBM siklus II telah berhasil memberi ketuntasan belajar dalam kelas. Nilai rata-rata kelas adalah 86,97 dengan standar deviasi 12,12. Data hasil formatif II ini dapat disajikan kembali dalam grafik histogram sebagai berikut:

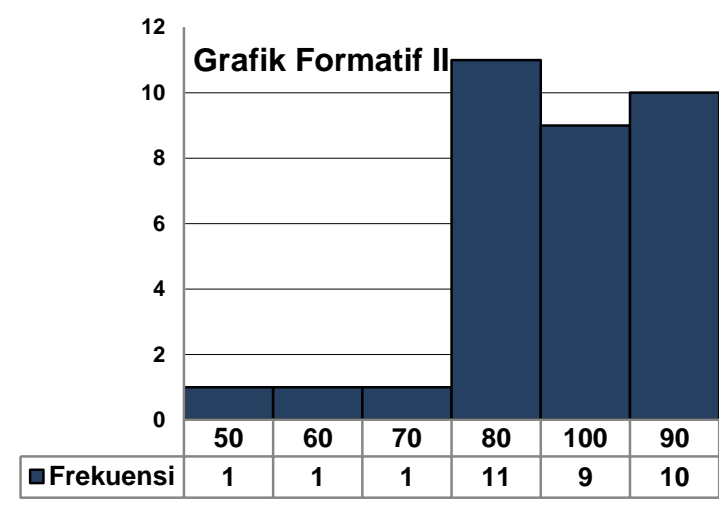

\section{Gambar .4.4 Grafik data hasil Formatif II}

Peningkatan hasil belajar di atas tidak terlepas dari peningkatan aktivitas belajar siswa selama pembelajaran. Penilaian aktivitas diperoleh dari lembar observasi aktivitas.Pengamatan dilakukan oleh dua pengamat selama 20 menit kerja kelompok dalam setiap KBM atau 40 menit dalam satu siklus.

\section{Pembahasan}

Berdasarkan hasil pelaksanaan pada siklus I dan II dapat dinyatakan bahwa terjadi peningkatan kualitas pembelajaran yang tampak dari perolehan hasil tes dan keaktifan siswa. Merujuk pada tabel 4.1 dan 4.2 dapat kita lihat adanya persentase kenaikan nilai siswa dari pretest dengan rata-rata 53,64 dan ketuntasan 0\% menjadi rata-rata 69,09 dangan ketuntasan klasikal 36,36\% pada formatif I. Hal itu menunjukkan bahwa pelaksanaan siklus I belum mencapai keberhasilan. Formatif II menunjukkan adanya peningkatan 
hasil belajar menjadi rata-rata 86,97. Hasil siklus II mendapatkan nilai rata-rata diatas KKM dan secara klasikal juga telah menunjukkan adanya keberhasilan pembelajaran dengan ketuntasan klasikal telah mencapai 90,90\%.

Dari data di atas dapat dilihat bahwa terjadi peningkatan kognitif siswa pada setiap siklusnya. Pada siklus pertama hasil belajar siswa tidak mencapai ketuntasan klasikal. Adapun hal-hal yang melatar belakanginya yakni:

a. Pembelajaran belum berpusat pada siswa

b. Bimbingan yang diberikan guru kurang menyeluruh.

c. Kelompok yang dibentuk guru tidak heterogen, karena berdasarkan letak tempat duduk siswa.

d. Guru tidak dapat menajemen waktu dengan baik, sehingga semua kegiatan dilakukan secara tergesa-gesa. Bahkan pada KBM II guru tidak membimbing siswa untuk menarik kesimpulan dengan baik.

Untuk menyusun rencana pada tindakan kelas siklus II maka perlu diadakan tindakan perbaikan terencana dari tindakan kelas siklus I. Berdasarkan hasil dari refleksi siklus I, maka beberapa tindakan yang disepakati antara peneliti dengan rekan kolaborasi (guru mata pelajaran yang sama, observer), adalah sebagai berikut: a. Proses pembelajaran harus berpusat pada siswa.

b. Perlu adanya umpan balik bagi siswa agar tahu sejauh manapemahaman mereka terhadap materi ajar yang disampaikan.

c. Meningkatkan bimbingan siswa secara menyeluruh.

d. Mengganti kelompok diskusi siswa menjadi kelompok diskusi yang heterogen, sehingga siswa yang pintar dapat membantu teman kelompoknya yang kemampuan kognitifnya rendah.

e. Guru harus pintar memanajemen waktu sehingga semua kegiatan pembelajaran dapat terlaksana dengan baik.

Setelah dilakukan refleksi dan tindakan perbaikan, pada siklus II hasil belajar siswa mengalami peningkatan yang cukup memuaskan. 30 orang siswa mencapai nilai lulus KKM, atau pun $90,90 \%$ tuntas secara klasikal. Sehingga pada refleksi II peneliti dapat menyimpulkan sebagai berikut:

a. Pembelajaran lebih banyak berpusat pada siswa. Hal ini terlihat dari peran guru yang sudah tidak terlalu dominan yakni hanya menjelaskan pemahaman awal yang kemudian akan dibahas oleh siswa secara lebih mendalam dalam diskusi kelompok. 
b. Guru juga sudah mulai dapat menempatkan diri sebagai motivator dan fasilitator.

c. Guru lebih banyak berkeliling kelas untuk memberikan bimbingan bagi siswa yang kurang paham.

d. Hampir semua siswa aktif dan memberikan respon yang baik pada pelajaran.

e. Kemampuan siswa dalam menyelesaikan masalah menunjukkan ke arah yang lebih baik.

Peningkatan hasil belajar siswa tidak terlepas dari meningkatnya aktivitas belajar siswa. Merujuk pada tabel 4.3,pada siklus I rata-rata aktivitas 1 yakni menulis dan membaca memperoleh Persentasi $47 \%$. Aktivitas mengerjakan dalam diskusi mencapai 34\%.Aktivitas bertanya pada teman sebesar 4\%.Aktivitas menjawab pertanyaan teman sebesar $4 \%$. Aktivitas bertanya kepada guru 3\% dan aktivitas yang tidak relevan dengan KBM sebesar 9\%. Nilai-nilai ini menunjukkan bahwa pola pembelajaran sudah berjalan tetapi belum maksimal. Dalam setiap pembahasan pembelajaran guru selalu melibatkan siswa secara aktif, namun hal ini masih belum nampak, karena siswa masih banyak yang malu-malu untuk menyampaikan apa yang diketahui kepada temannya dan hanya melakukan kegiatan menulis dan membaca. Guru memberi kesempatan bertanya selama pengembangan, tetapi siswa kurang berani untuk bertanya walaupun belum jelas, siswa akan berani bertanya jika ada teman lain yang bertanya terlebih dahulu, atau apabila guru memberikan bimbingan secara individual pada setiap siswa dalam mengerjakan soal latihan.

Pada siklus II aktivitas menulis dan membaca turun menjadi $31 \%$ mengingat nilai ini cukup tinggi sepertinya mengindikasikan bahwa masih banyak siswa lebih tertarik berdiam diri dengan hanya duduk dan menuli-nulis tidak ikut bekerja. Namun menurunnya aktivitas menulis dan membaca juga mengindikasikan bagwa beberapa siswa menjadi lebih aktif dari sebelumnya. Aktivitas mengerjakan dalam diskusi yang meningkat menjadi $44 \%$, hal ini menunjukkan perbaikan yang terjadi dalam proses pembelajaran seperti yang diharapkan, di mana siswa lebih banyak mengerjakan LKS dan berdiskusi dari pada membaca dan menulis di kelas. Sementara aktivitas bertanya pada teman ikut naik menjadi $11 \%$ sejalan dengan meningkatnya aktivitas menjawab pertanyaan teman menjadi $9 \%$, dan bertanya pada guru justru turun menjadi $1 \%$ dalam hal ini berarti siswa telah terlatih untuk menyelesaikan masalah secara diskusi dengan teman sekelompok dan berkurang tingkat ketergantungannya pada peneliti/ guru. Perbaikan pembelajaran diperkuat dengan temuan bahwa aktivitas yang tidak relevan dengan KBM pada siklus II menyusut 
mencapai 3\%, yang mengindikasikan bahwa siswa lebih serius dalam melaksanakan diskusi sehingga tindakan yang tidak relevan dengan KBM menjadi menyusut. Setelah dilakukan diskusi, maka akan dilakukan sesi tanya jawab di kelas, selama sesi tanya jawab, pada siklus I tidak ada siswa yang mau bertanya, sehingga penarikan kesimpulan lebih cenderung dilakukan oleh guru, sedangkan pada siklus II, ada beberapa siswa yang bertanya pada sesi tanya jawab dan ada pula beberapa siswa yang memeberikan pendapat, hal ini turut menandakan bahwa terjadi peningkatan aktivitas belajar siswa selama KBM.

Karena keterbatasan waktu, biaya, dan tenaga maka peneliti hanya membatasi penelitian sampai pada siklus II. Sehingga peneliti tidak melakukan tindakan perbaikan dan melanjutkan penelitian pada siklus III, keputusan ini juga diambil mengingat nilai siswa sudah mencapai ketuntasan klasikal, dimana siswa memperoleh nilai lulus KKM lebih dari $85 \%$.

\section{SIMPULAN DAN SARAN \\ Simpulan}

Adapun kesimpulan dari penerapan model pembelajaran Snowball Throwing selama kegiatan pembelajaran pada materi pokok Hubungan Internasional di kelas XI IPA-1 SMA Negeri 1 Panyabungan sebagai berikut: a. Penerapan model pembelajaran Snowball Throwing selama kegiatan pembelajaran pada materi Hubungan Internasional di kelas XI IPA-1 SMA Negeri 1 Panyabungan dapat meningkatkan keterampilan siswa dalam mengemukakan pendapat, hal ini ditandai dengan aktivitas siswa yang semakin meningkat setiap siklusnya dan sikap antusias siswa setiap siklusnya dalam pembelajaran PKn di kelas XI IPA-1 SMA Negeri 1 Panyabungan.

b. Penerapan model pembelajaran Snowball Throwing diterapkan dengan membagikan kertas kerja kepada setiap siswa dan menuliskan pertanyaan untuk diberikan kepada temannya yang lain, sesuai dengan waktu yang telah ditentukan guru memanggil siswa untuk membaca dan menjawab pertanyaan yang diajukan oleh temannya dalam kertas bola yang dibuat temannya. Dalam hal ini seluruh siswa antusias dalam menjawab setiap pertanyaan yang diajukan.

c. Hasil belajar siswa pada materi Hubungan Internasional dengan menerapkan model pembelajaran Snowball Throwing pada Siklus I mencapai rata-rata 69,09 dengan ketuntasan klasikal 36,36\% dan Siklus II mencapai 86,97 dengan ketuntasan klasikal 90,90\%. Dengan demikian terjadi peningkatan hasil belajar dan ketuntasan belajar siswa pada materi pokok Hubungan Internasional di kelas XI IPA-1 
SMA Negeri 1 Panyabungan

Tahun Pelajaran 2014/2015.

\section{Saran}

Setelah melakukan kegiatan belajar mengajar selama empat kali atau disebut dua siklus maka perlu saran agar pengguna atau yang memanfaatkan model pembelajaran Kooperatif Tipe Snowball Throwing di sekolah benar-benar bermanfaat sesuai dengan tujuan penelitian.

1. Setting kelas sebaiknya mudah untuk mengatur meja-meja di dalam kelas, sehingga membentuk kelompok dapat dilaksanakan dalam waktu yang singkat.

2. Selama kerja kelompok perlu diarahkan agar terjadi saling bekerja sesama siswa dalam satu kelompok.

3. Pemanfaatan LKS dapat digunakan agar siswa lebih termotivasi dan tertuntun dalam membangun konsep sendiri.

4. Dalam menerapkan model pembelajaran sebaiknya siswa telah paham keuntungan dan fungsi posisi dirinya dalam kelompok sehingga siswa mudah mengikuti kegiatan belajar mengajar.

5. Dalam setengah dari KBM yang dijadwalkan dalam penelitian sebaiknya dilakukan pertukaran anggota kelompok untuk mengurangi kebosanan dan kemungkinan ketergantungan antar siswa serta pemusatan aktivitas pada kelompokkelompok tertentu saja.

\section{DAFTAR PUSTAKA}

Ainurrahman, (2009). Belajar dan Pembelajaran. Bandung : Alfabeta

Aqib, Zainal. (2006).Penelitian Tindakan Kelas. Yrama Widya. Bandung.

Arikunto, S. 2006. Prosedur Penelitian Suatu Pendekatan Praktik. Jakarta: Rineka Cipta

Ibrahim, M., dkk. (1988). Pembelajaran kooperatif. Universitas Negeri Surabaya. Surabaya.

Lie, A. (2004).Cooperatif Learning Memperaktekkan Cooperatif Learning di Ruang-Ruang Kelas. PT Grasindo. Jakarta. Sagala. (2003). Konsep dan Makna Pembelajaran. Alfabeta. Bandung.

Sardiman.(2006).Interaksi, dan Motivasi Belajar Mengajar.

Raja

GrafindoPersada.Jakarta. Slameto.(2003). Belajar dan FaktorFaktor yang

Mempengaruhinya.Rineka

Cipta.Jakarta

Suprapto, dkk. 2015. Pendidikan Kewarganegaraan SMA Kelas XI. Bumi Aksara. Jakarta 